\title{
Study on the Permeability of Modified Bentonite Slurry in Landfill
}

\author{
Zenan Zhang, Guozhong Dai (iD, and Yanmin Sheng \\ School of Civil Engineering \& Architecture, Changzhou Institute of Technology, Changzhou 213032, China \\ Correspondence should be addressed to Guozhong Dai; daigz@czu.cn
}

Received 27 July 2020; Revised 20 September 2020; Accepted 30 October 2020; Published 24 November 2020

Academic Editor: Charles C. Sorrell

Copyright $(2020$ Zenan Zhang et al. This is an open access article distributed under the Creative Commons Attribution License, which permits unrestricted use, distribution, and reproduction in any medium, provided the original work is properly cited.

\begin{abstract}
The impermeability of cutoff wall is one of the most important factors affecting the life of landfill. Hence, we used sodium carboxymethyl cellulose to modify bentonite and developed a modified bentonite-cement-fly ash antiseepage slurry with a low permeability coefficient. The main material of the slurry is bentonite modified by sodium carboxymethyl cellulose, cement, fly ash, and auxiliary materials such as sodium carbonate and polycarboxylate superplasticizer. The optimal ratio of the basic components of the antiseepage slurry was optimized by the orthogonal test method. The permeability coefficient of the consolidated slurry was determined by a variable head permeameter. The optimal dosage of each component of slurry is $210 \sim 220 \mathrm{~kg} / \mathrm{m}^{3} \mathrm{cement}$, $210 \sim 220 \mathrm{~kg} / \mathrm{m}^{3}$ bentonite, $1.5 \sim 2.5 \mathrm{~kg} / \mathrm{m}^{3}$ sodium carbonate, $1.5 \sim 2.0 \mathrm{~kg} / \mathrm{m}^{3}$ sodium carboxymethyl cellulose, $160 \mathrm{~kg} / \mathrm{m}^{3} \mathrm{fly}$ ash, and $3 \mathrm{~kg} / \mathrm{m}^{3}$ polycarboxylate superplasticizer. The 28-day consolidation slurry permeability coefficient is less than $1 \times 10^{-8} \mathrm{~cm} / \mathrm{s}$ and has a good adsorption effect on the pollutants in landfill leachate.
\end{abstract}

\section{Introduction}

In recent years, with the rapid development of urbanization in China, the number of urban population is expanding day by day [1]. As a result, the annual accumulation of municipal solid waste has increased dramatically. In some areas, there has been a phenomenon of "garbage siege" $[2,3]$. If not properly handled, it will cause extremely strong pollution to the surrounding environment [4-6]. Sanitary landfill and incineration methods are widely used to treat urban household garbage in China. During the $12^{\text {th }}$ five-year plan period, sanitary landfill accounts for $66 \%$, incineration for $31 \%$ and the rest for 3\% [7-9]. At present, there are nearly 700 sanitary landfill sites in China, with nearly 120 million tons of garbage treated innocently, and the disposal volume is very considerable. However, with the development of the economy, there are more and more kinds of urban household garbage, and the pollution is also getting stronger $[10,11]$. Because the landfills have their own moisture, and in the long-term erosion of rainwater and groundwater, through the landfills and the overlying soil, it will form a high concentration of wastewaterlandfill leachate [12]. The composition of the landfill leachate is complex and variable, with uncertainty. Generally, with the high concentration of $\mathrm{COD}_{\mathrm{cr}}, \mathrm{BOD}_{5}$, heavy metals, and ammonia nitrogen components, this leachate pollution is strong and difficult to deal with [13].

If the antiseepage system of landfills cracks and penetrates, landfill leachate will invade the surrounding environment, and its main hazards include the following aspects: first, it will pollute the surface water and groundwater [14]. China has a large population and a small per capita water supply, making it one of the poorest countries in per capita water resources in the world [15]. Polluted groundwater cannot be used as domestic water source, which will seriously affect people's use of natural resources. Second, it will contaminate the surrounding soil, which cannot be used as farmland or forest land [16]. Moreover, it is difficult to control soil pollution, and it is difficult to achieve results in a short period of time. Third, it will endanger human health. Heavy metal ions in leachate also accumulate in the human body through products in water and plants in soil, which will cause serious social events [17]. Moreover, due to the complexity of the composition of landfill leachate, these damages to the surrounding environment will last for a long time and are difficult to be comprehensively treated. At present, there is no effective and efficient governance method. Once leak consumes huge manpower and material resources, incalculable economic loss occurs [18]. Therefore, 
the landfill project must be effectively guaranteed to ensure that there will not be any leakage accidents. Seepage prevention is the core of landfill, which determines the life of landfills [19-21]. How to effectively control and treat landfill leachate has become one of the unavoidable problems in environmental geotechnical engineering.

It is stipulated in the technical specification for sanitary landfill of municipal solid waste issued now that proper artificial seepage prevention measures must be established for landfill sites that do not have natural seepage prevention conditions and landfill leachate that may pollute underground water sources [22-24]. Artificial seepage prevention is the use of artificial landfill bottom, four walls, and top surface treatment and enhances the landfill impermeability [25-27]. At present, the way of establishing a cutoff wall is often used to prevent seepage. In this paper, based on the traditional bentonite-fly ash-cement (BFC) impermeable slurry material [28-30], sodium carboxymethyl cellulose (CMC) was used as a modifier to organically treat bentonite, thus forming a composite material. The slurry is of moderate strength. It can not only coordinate with the soil around the landfill site for deformation but also has a stronger impermeability, which can better meet the requirements of landfill site for the impermeable wall. The proportion of each component of slurry has an important influence on the impermeability of the slurry consolidation body [31]. In this paper, the optimum range of the dosage of each component was studied by an orthogonal experiment. Then, the influence of a single component on slurry consolidation body was analyzed by factor influence analysis. The microscopic mechanism of each component influencing the impermeability of slurry consolidated body was analyzed by SEM. Finally, a self-made adsorption percolation device was used to detect the adsorption effect of slurry consolidation diagram on the main pollutants.

\section{Experiment}

2.1. Materials. The main raw materials of antiseepage slurry are bentonite, cement, and fly ash, and the modifier is sodium carboxymethyl cellulose. Sodium carbonate and polycarboxylate water reducer were used as additives. Calcium bentonite is selected as bentonite, and the main performance parameters are shown in Table 1 . The cement is ordinary Portland cement with a strength grade of 42.5. Sodium carbonate and sodium carboxymethyl cellulose are of analytical pure grade. The water reducer is TOJ800-10A polycarboxylic acid water reducer. Fly ash is a grade I ash.

2.2. Sample Preparation. When preparing the sample, the bentonite was first nitrified. A certain amount of bentonite was weighed and poured it into a beaker. A solution of sodium carbonate of a certain concentration is then poured into the bentonite and stirred well. The prepared carboxymethyl cellulose sodium solution was poured into the nitrified bentonite and left for more than 8 hours for modification. After the modification, a certain amount of cement and fly ash were mixed into the modified bentonite.
Finally, the superplasticizer solution was added with a certain amount of water and stirred thoroughly to make the components evenly distributed. During this process, it is necessary to pay attention to the amount of water so that the slurry stirred evenly can be pumped for more than $40 \mathrm{~min}$. The evenly mixed slurry was poured into a round mould to form a slurry strength sample. The size of the sample of impermeable slurry was cut with a circular ring knife of $61.8 \times 40 \mathrm{~mm}$. The sample of impermeable slurry was placed in water for curing. After curing for 14 days and 28 days, the samples are shown in Figure 1.

2.3. Test Sample Permeability Coefficient. The permeability coefficient of impermeable slurry was measured by a variable head penetrator. The variable head penetrator is shown in Figure 2.

After the test sample reaches the curing period, it is taken out for testing. Firstly, the slurry consolidated body sample was put into the permeation device, and the nut was tightened. Next, the inlet of the permeation device and the inlet pipe of the variable head permeameter were opened and the pipe clamp to let the water from the water supply bottle into the instrument was opened. Then, the exhaust valve was opened, and the air from the tube was removed until there are no bubbles in the outgoing water. Finally, water is injected into the variable manifold, and the timer is started when the outlet has water flowing out. The initial head was recorded, and then, the head position at regular intervals was recorded. The permeability coefficient of slurry consolidation body is calculated according to the following formula:

$$
k_{T}=2.3 \frac{a L}{A\left(t_{2}-t_{1}\right)} \lg \frac{H_{2}}{H_{1}} .
$$

The permeability coefficient of block measured by the variable head test method is derived from the Chinese geotechnical test method standard, where $a$ is the crosssectional area $\left(\mathrm{cm}^{2}\right)$ of the variable head tube, $L$ is the height of the sample $(\mathrm{cm}), A$ is the section area of the test sample $\left(\mathrm{cm}^{2}\right), H_{1}$ and $H_{2}$ are the starting and ending water heads (cm) in the pipe, and $T_{1}$ and $T_{2}$ are the time at the beginning and the end of the reading $(s)$.

2.4. Orthogonal Experimental Method. In order to study the influence of each component on the slurry experiment, a large-scale experiment is needed. It is not only difficult to operate but also can produce great errors due to experimental conditions. Therefore, combining with the previous experimental results, we decided to adopt the orthogonal experimental method. It not only greatly reduced the number of experiments but also can meet the experimental requirements.

According to the previous experiments, it is decided to carry out orthogonal experiments on the components which have a great influence on the performance of slurry: the cement content is $190 \sim 220 \mathrm{~kg} / \mathrm{m}^{3}$, the bentonite content is $190 \sim 220 \mathrm{~kg} / \mathrm{m}^{3}$, the CMC-Na content is $0.5 \sim 2.0 \mathrm{~kg} / \mathrm{m}^{3}$, and the sodium carbonate content is $1.0 \sim 2.5 \mathrm{~kg} / \mathrm{m}^{3}$. The 
TABle 1: Performance indicators of bentonite.

\begin{tabular}{lcccccc}
\hline $\begin{array}{l}\text { Colloid valence } \\
(\mathrm{ml} / 15 \mathrm{~g} \pm)\end{array}$ & $\begin{array}{c}\text { Granularity (mesh } \\
\text { number })\end{array}$ & $\begin{array}{c}\text { Ion exchange capacity } \\
(\mathrm{meg} / 100 \pm)\end{array}$ & $\begin{array}{c}\text { Initial moisture } \\
\text { content }(\%)\end{array}$ & $\begin{array}{c}\text { Liquid limit } \\
(\%)\end{array}$ & $\begin{array}{c}\text { Plastic limit } \\
(\%)\end{array}$ & $\begin{array}{c}\text { Plasticity index } \\
(\%)\end{array}$ \\
\hline 90 & 180 & $>70$ & 10.0 & 260 & 40 & 237 \\
\hline
\end{tabular}

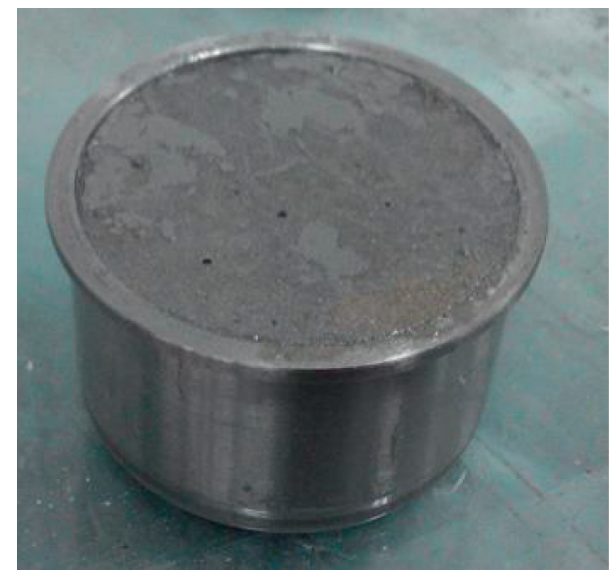

Figure 1: Slurry test sample.

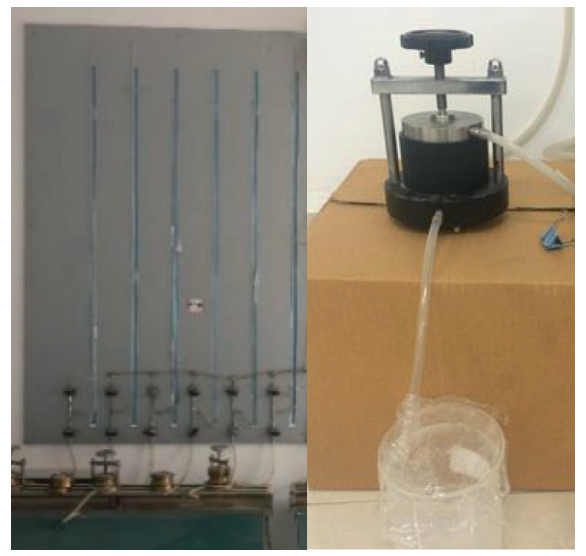

Figure 2: The variable head permeameter.

remaining components had less effect on the experiment, taking the fixed value: the fly ash dosage was $160 \mathrm{~kg} / \mathrm{m}^{3}$, and the amount of water reducer was $3 \mathrm{~kg} / \mathrm{m}^{3} . L^{16}\left(4^{4}\right)$ orthogonal experiment with four factors and three levels was used to optimize the proportion of slurry. The orthogonal experiment is shown in Table 2.

2.5. Range Analysis. In order to find out the optimum level of each component and to make the primary and secondary sequential mining of each component which affects the permeability coefficient of slurry consolidation body, the orthogonal experimental data were analyzed by the method of range analysis. The analysis of permeability coefficient range difference of slurry consolidation body at 14 days and 28 days is shown in Tables 3 and 4, respectively.

According to the range analysis table, the influence trend curve of each component on the permeability coefficient of samples in different periods is shown in Figure 3.
Tables 3 and 4 and Figure 3 show that the permeability coefficient of slurry consolidation body decreases with the increase in the content of cement, sodium carbonate, and sodium carboxymethyl cellulose in each period. At day 14, the permeability coefficient of slurry consolidation body decreased first and then increased with the increase in bentonite content, with a minimum value. It indicates that there is an optimal interval between 210 and $220 \mathrm{~kg} / \mathrm{m}^{3}$ for the content of bentonite. At 28 days, with the increase in bentonite content, the permeability coefficient of slurry consolidation body decreases gradually.

At 14 days, the influence of each factor content on the permeability coefficient of the slurry consolidation body was ranked from large to small: cement, sodium carboxymethyl cellulose, bentonite, and sodium carbonate. At 28 days, the influence of various factors on the permeability coefficient of slurry consolidation body was as follows: bentonite, cement, sodium carboxymethyl cellulose, and sodium carbonate. At 28 days, bentonite replaced cement as the main factor affecting the permeability coefficient of the slurry consolidation body.

In order to obtain a lower permeability coefficient, the content of each component of slurry is controlled in the following range: cement $210 \sim 220 \mathrm{~kg} / \mathrm{m}^{3}$, swelling $210 \sim 220 \mathrm{~kg} / \mathrm{m}^{3}$, sodium carbonate $2.0 \sim 2.5 \mathrm{~kg} / \mathrm{m}^{3}$, and sodium carboxymethyl cellulose $1.5 \sim 2.0 \mathrm{~kg} / \mathrm{m}^{3}$.

Sodium carbonate and sodium carboxymethyl cellulose, as modifiers of bentonite, affect the expansibility of bentonite by modifying the bentonite, thus affecting the permeability coefficient of the sample. The coupling effect among its factors is not considered in the orthogonal experiment. Therefore, it is necessary to carry out factor influence analysis to further analyze the relationship between factors and slurry permeability coefficient.

2.6. Factor Influence Analysis. First, the influence of cement and bentonite content on the permeability coefficient of samples was analyzed. According to the orthogonal experiment results, with $210 \mathrm{~kg} / \mathrm{m}^{3}$ cement, $210 \mathrm{~kg} / \mathrm{m}^{3}$ bentonite, $2.0 \mathrm{~kg} / \mathrm{m}^{3}$ sodium carbonate, and $1.5 \mathrm{~kg} / \mathrm{m}^{3}$ sodium carboxymethyl cellulose, except for water, the content of other materials is not changed into the benchmark ratio. The control cement content is $210 \sim 250 \mathrm{~kg} / \mathrm{m}^{3}$, and bentonite content is $200 \sim 240 \mathrm{~kg} / \mathrm{m}^{3}$. The permeability coefficients of samples with different cement and bentonite contents were tested, respectively, and the specific proportions are shown in Table 5.

The influence curves of cement with different contents on the permeability coefficient of samples drawn from Table 6 are shown in Figure 4 . The influence curves of bentonite with different contents on the permeability coefficient of samples drawn from Table 5 are shown in Figure 5. 
TABLE 2: Orthogonal experimental scheme.

\begin{tabular}{lccccc}
\hline Number & Cement $\left(\mathrm{kg} / \mathrm{m}^{3}\right)$ & Bentonite $\left(\mathrm{kg} / \mathrm{m}^{3}\right)$ & Sodium carbonate $\left(\mathrm{kg} / \mathrm{m}^{3}\right)$ & CMC-Na $\left(\mathrm{kg} / \mathrm{m}^{3}\right)$ & $\begin{array}{c}\text { Permeability coefficient } \\
(\mathrm{cm} / \mathrm{s})\end{array}$ \\
\hline 1 & & & & 0.50 & $7.30 E-06$ \\
$28 \mathrm{~d}$
\end{tabular}

TABLE 3: Range analysis of 14-day permeability coefficient of samples.

\begin{tabular}{|c|c|c|c|c|c|}
\hline Number & & $\begin{array}{c}A \\
\text { Cement }\end{array}$ & $\begin{array}{c}B \\
\text { Bentonite }\end{array}$ & $\begin{array}{c}C \\
\text { Sodium carbonate }\end{array}$ & $\begin{array}{c}D \\
\text { CMC-Na }\end{array}$ \\
\hline \multirow{4}{*}{ Content $\left(\mathrm{kg} / \mathrm{m}^{3}\right)$} & 1 & 190 & 190 & 1.00 & 0.50 \\
\hline & 2 & 200 & 200 & 1.50 & 1.00 \\
\hline & 3 & 210 & 210 & 2.00 & 1.50 \\
\hline & 4 & 220 & 220 & 2.50 & 2.00 \\
\hline \multirow{4}{*}{ Permeability coefficient $(\mathrm{cm} / \mathrm{s})$} & $\bar{K} 1$ & $5.33 E--06$ & $4.33 E-06$ & $3.88 E-06$ & $4.90 E-06$ \\
\hline & $\bar{K} 2$ & $4.63 E-06$ & $3.68 E-06$ & $4.06 E-06$ & $3.65 E-06$ \\
\hline & $\bar{K} 3$ & $2.65 E-06$ & $3.03 E-06$ & $3.50 E-06$ & $3.20 E-06$ \\
\hline & $\bar{K} 4$ & $1.96 E-06$ & $3.25 E-06$ & $3.13 E-06$ & $2.81 E-06$ \\
\hline \multirow{2}{*}{\multicolumn{2}{|c|}{ Excellent level range }} & $A 4$ & B3 & $C 4$ & D4 \\
\hline & & $3.37 E-06$ & $1.30 E-06$ & $9.30 E-07$ & $2.10 E-06$ \\
\hline \multicolumn{2}{|l|}{ Primary and secondary order } & \multicolumn{4}{|c|}{$A>D>B>C$} \\
\hline
\end{tabular}

TABLE 4: Range analysis of 28-day permeability coefficient of samples.

\begin{tabular}{|c|c|c|c|c|c|}
\hline Number & & $\begin{array}{c}A \\
\text { Cement }\end{array}$ & $\begin{array}{c}B \\
\text { Bentonite } \\
\end{array}$ & $\begin{array}{c}C \\
\text { Sodium carbonate } \\
\end{array}$ & $\begin{array}{c}D \\
\text { CMC-Na } \\
\end{array}$ \\
\hline \multirow{4}{*}{ Content $\left(\mathrm{kg} / \mathrm{m}^{3}\right)$} & 1 & 190 & 190 & 1.00 & 0.50 \\
\hline & 2 & 200 & 200 & 1.50 & 1.00 \\
\hline & 3 & 210 & 210 & 2.00 & 1.50 \\
\hline & 4 & 220 & 220 & 2.50 & 2.00 \\
\hline \multirow{4}{*}{ Permeability coefficient $(\mathrm{cm} / \mathrm{s})$} & $\bar{K} 1$ & $1.25 E--08$ & $1.24 E-08$ & $9.80 E-09$ & $1.01 E-08$ \\
\hline & $\bar{K} 2$ & $9.08 E-09$ & $9.05 E-09$ & $8.88 E-09$ & $8.38 E-09$ \\
\hline & $\bar{K} 3$ & $5.13 E-09$ & $5.70 E-09$ & $6.73 E-09$ & $7.33 E-09$ \\
\hline & $\bar{K} 4$ & $5.03 E-09$ & $4.58 E-09$ & $6.35 E-09$ & $5.95 E-09$ \\
\hline \multirow{2}{*}{ Excellent level range } & & $A 4$ & $B 4$ & C4 & D4 \\
\hline & & $7.50 E-09$ & $7.85 E-09$ & $3.08 E-09$ & $4.15 E-09$ \\
\hline Primary and secondary order & & \multicolumn{4}{|c|}{$\begin{array}{c}B \\
B>A>D>C\end{array}$} \\
\hline
\end{tabular}

It can be seen from Table 5 and Figures 4 and 5 that cement is the main factor influencing the permeability coefficient of samples at 14 days. The cement content increased from $210 \mathrm{~kg} / \mathrm{m}^{3}$ to $250 \mathrm{~kg} / \mathrm{m}^{3}$, and the permeability coefficient of the sample decreased from $2.10 \times 10^{-6} \mathrm{~cm} / \mathrm{s}$ to
$8.30 \times 10^{-7} \mathrm{~cm} / \mathrm{s}$, a decrease of $1.27 \times 10^{-6} \mathrm{~cm} / \mathrm{s}$. The bentonite content increased from $200 \mathrm{~kg} / \mathrm{m}^{3}$ to $240 \mathrm{~kg} / \mathrm{m}^{3}$, and the 14-day permeability coefficient of the sample decreased first and then slightly increased and tended to be flat, which decreased by $8.80 \times 10^{-7} \mathrm{~cm} / \mathrm{s}$ compared with the lowest 


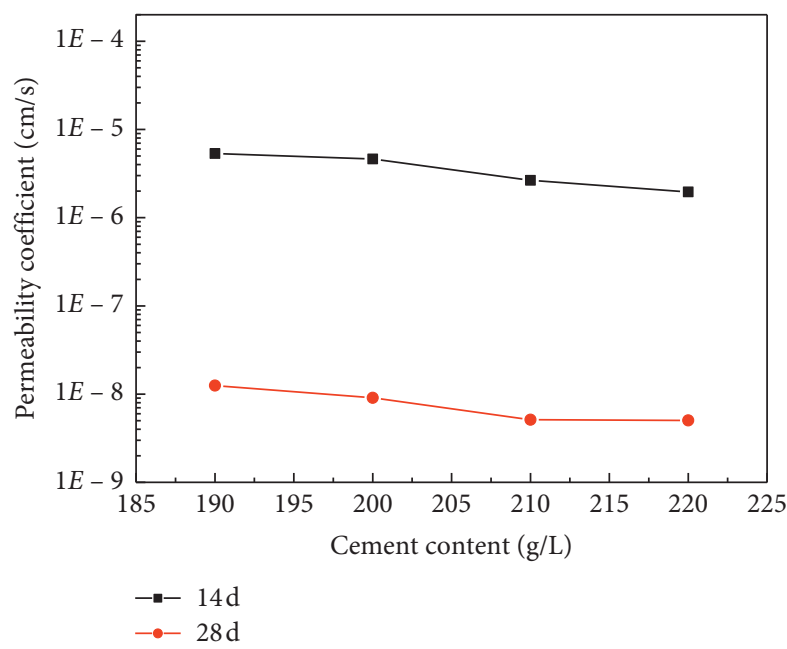

(a)

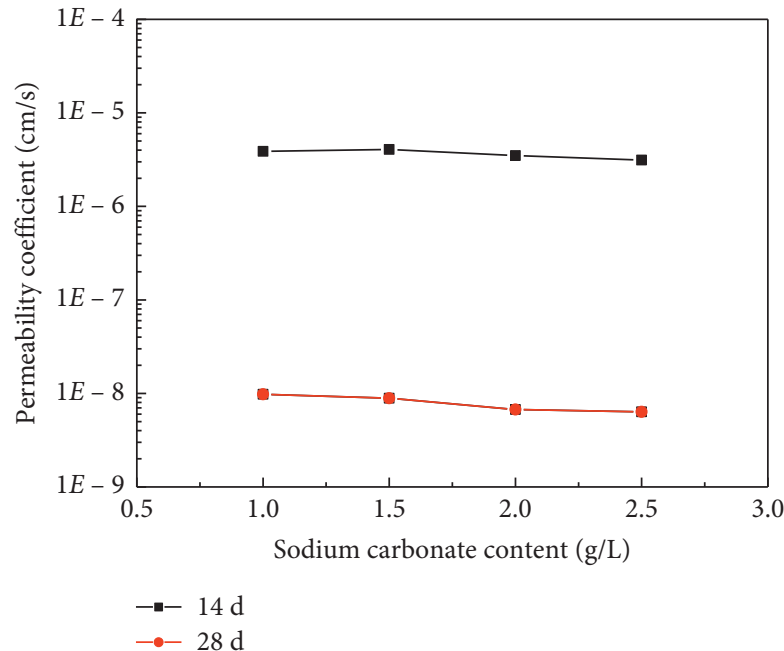

(c)

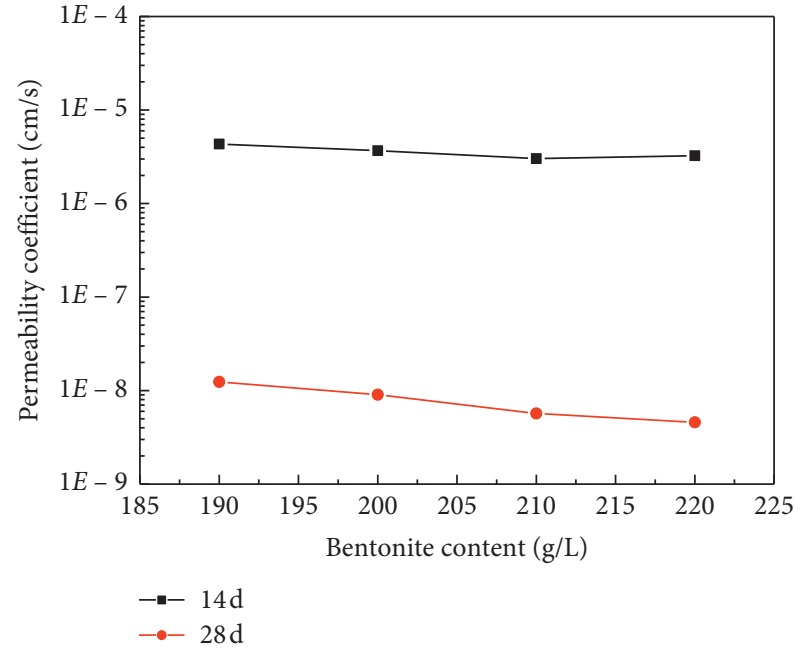

(b)

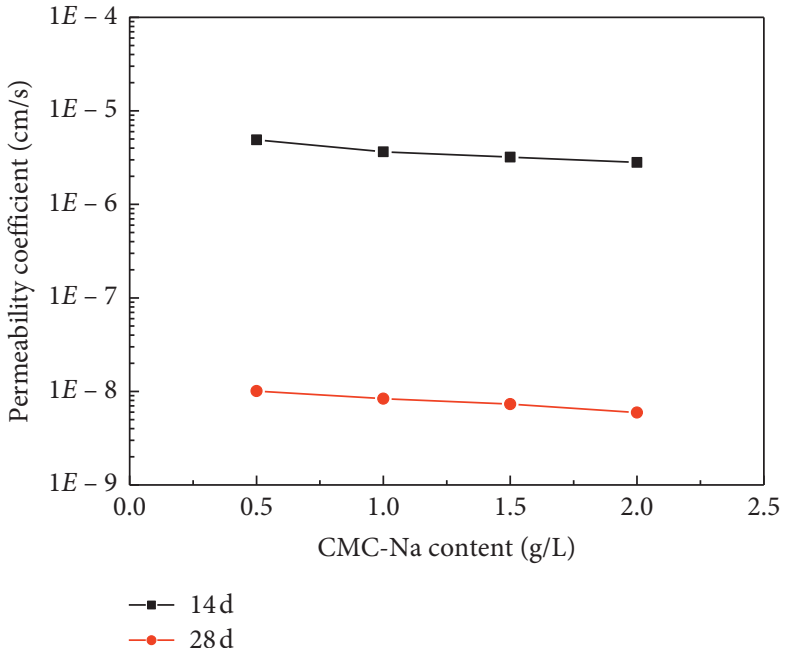

(d)

FIGURE 3: (a) Curve of influence of cement content on sample permeability coefficient; (b) curve of influence of bentonite content on sample permeability coefficient; (c) curve of influence of sodium carbonate content on sample permeability coefficient; (d) curve of influence of CMC-Na content on sample permeability coefficient.

TABLE 5: Effects of cement and bentonite content on permeability coefficient of test sample.

\begin{tabular}{lcccc}
\hline \multirow{2}{*}{ Number } & Cement $\left(\mathrm{kg} / \mathrm{m}^{3}\right)$ & Bentonite $\left(\mathrm{kg} / \mathrm{m}^{3}\right)$ & \multicolumn{2}{c}{ Permeability coefficient $(\mathrm{cm} / \mathrm{s})$} \\
\hline$A 1$ & & & $14 \mathrm{~d}$ & $28 \mathrm{~d}$ \\
$A 2$ & 210 & 210 & $2.10 E-06$ & $4.90 E-09$ \\
$A 3$ & 220 & 210 & $1.20 E-06$ & $2.30 E-09$ \\
$A 4$ & 230 & 210 & $1.00 E-06$ & $1.70 E-09$ \\
$A 5$ & 240 & 210 & $9.10 E-07$ & $1.60 E-09$ \\
$B 1$ & 250 & 200 & $8.30 E-07$ & $1.50 E-09$ \\
$B 2$ & 210 & 210 & $1.70 E-06$ & $5.30 E-09$ \\
$B 3$ & 210 & 220 & $1.10 E-06$ & $3.80 E-09$ \\
$B 4$ & 210 & 230 & $7.60 E-07$ & 2.09 \\
$B 5$ & 210 & 240 & $7.90 E-07$ & $1.50 E-09$ \\
& 210 & $8.20 E-07$ & $1.60 E-09$ \\
\end{tabular}




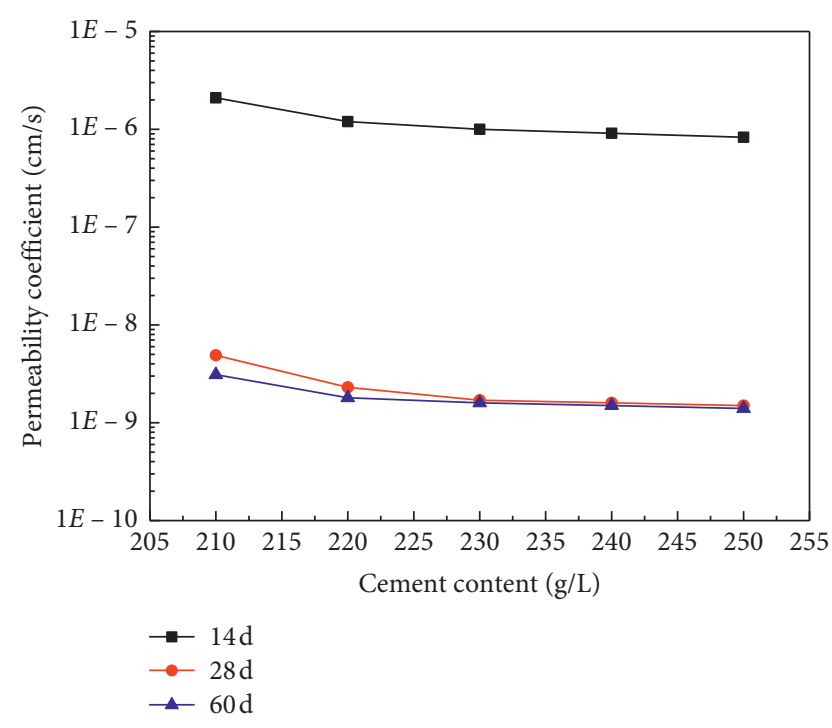

Figure 4: Curve of influence of different cement contents on permeability coefficient of samples.

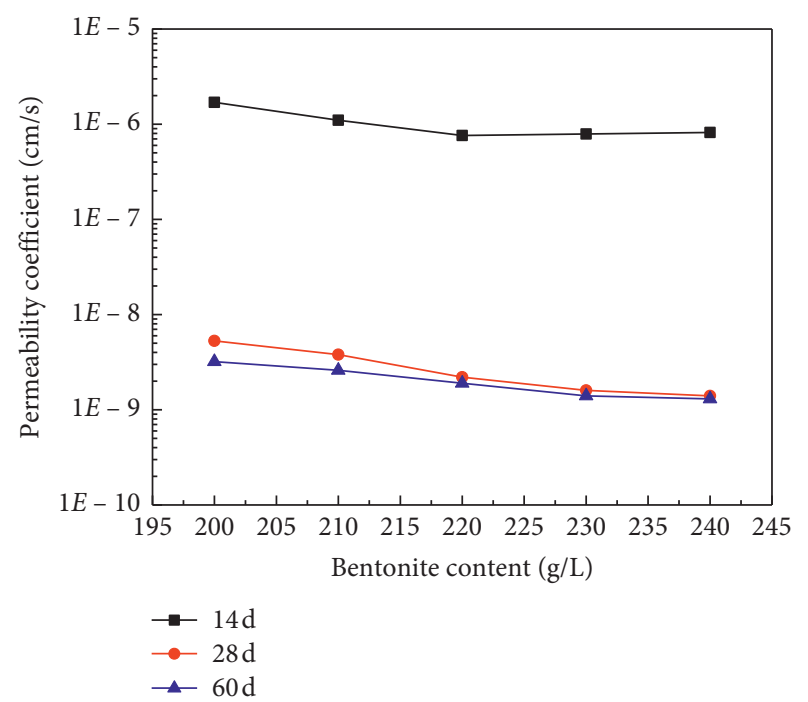

Figure 5: Curve of influence of different bentonite contents on permeability coefficient of samples.

point. Bentonite was the main factor influencing the 28-day permeability coefficient of the sample, and the curve showed a trend of gradual decrease and flattening, which was basically consistent with the orthogonal experiment. The trend of the permeability coefficient curve at 60 days is basically the same as that at 28 days, with a small variation and a flat curve.

Then, the influence of sodium carbonate and sodium carboxymethyl cellulose on the permeability coefficient of the sample was analyzed. Sodium carbonate is the nitrifier of bentonite and sodium carboxymethyl cellulose is the modifier of bentonite. By acting on bentonite, they changed the water absorption and expansion coefficient of bentonite so as to influence the permeability coefficient of the sample.
According to the orthogonal experiment results, with $210 \mathrm{~kg} / \mathrm{m}^{3}$ cement, $210 \mathrm{~kg} / \mathrm{m}^{3}$ bentonite, $2.0 \mathrm{~kg} / \mathrm{m}^{3}$ sodium carbonate, and $1.5 \mathrm{~kg} / \mathrm{m}^{3}$ sodium carboxymethyl cellulose, except for water, the content of other materials does not change into the benchmark ratio. The sodium carbonate content was controlled to be $1 \sim 3 \mathrm{~kg} / \mathrm{m}^{3}$, and the sodium carboxymethyl cellulose content was $0.5 \sim 2.5 \mathrm{~kg} / \mathrm{m}^{3}$. The permeability coefficients of samples with different sodium carbonate and sodium carboxymethyl cellulose contents were tested, respectively, and the specific proportions are shown in Table 6.

The influence curves of sodium carbonate with different contents on the permeability coefficient of samples drawn from Table 6 are shown in Figure 6. The influence curves of sodium carboxymethyl cellulose of different dosages on the permeability coefficient of samples drawn from Table 5 are shown in Figure 7.

When the content of sodium carbonate increases from $1.0 \mathrm{~g}$ to $2.0 \mathrm{~g}$ during the curing period of 14 and 28 days, the permeability coefficient of the sample decreases significantly. When the content of sodium carbonate increased from $2.0 \mathrm{~g}$ to $3.0 \mathrm{~g}$, the permeability coefficient curve of the sample was relatively flat and hardly changed. In each period of sample curing, with the increase in sodium carboxymethyl cellulose content, the permeability coefficient of the sample showed a gradually decreasing trend. However, the decreasing trend in the later period became more and more gradual, with almost no change. In addition, during the curing period of 60 days, the permeability coefficient of the sample decreased more smoothly than that at 14 days and 28 days. The general variation trend is consistent with the orthogonal experiment.

\subsection{Adsorption Retardation Test of Slurry Consolidation Body.} The adsorption performance of the slurry consolidation body was tested by the self-made adsorption percolation apparatus, as shown in Figure 8. Slurry adopts the following composition ratio: cement $210 \mathrm{~kg} / \mathrm{m}^{3}$, swelling $220 \mathrm{~kg} / \mathrm{m}^{3}$, sodium carbonate $2.0 \mathrm{~kg} / \mathrm{m}^{3}$, sodium carboxymethyl cellulose $1.5 \mathrm{~kg} / \mathrm{m}^{3}$, fly ash $160 \mathrm{~kg} / \mathrm{m}^{3}$, and polycarboxylic acid water reducer $3 \mathrm{~kg} / \mathrm{m}^{3}$.

The adsorption and retarding properties of the slurry were tested with artificial leachate in the laboratory. The main components of leachate are shown in Table 7.

The results of the adsorption retardation test on the percolate by the cementing body of impermeable slurry were compared with the discharge standards of various pollutants to evaluate its adsorption retardation performance. The adsorption retardation test results of slurry consolidation body to leachate are shown in Table 8 .

After modified by sodium carboxymethyl cellulose, the adsorption effect of bentonite to various pollutants has been improved to some extent. The adsorption effect of modified bentonite slurry on heavy metal ions and ammonia nitrogen ions reached over $99.80 \%$, and the adsorption effect of dibutyl phthalate was significantly improved, which could meet the specified emission requirements. 
TABLE 6: Effects of sodium carbonate and CMC-Na content on permeability coefficient of test samples.

\begin{tabular}{lcccc}
\hline \multirow{2}{*}{ Number } & Sodium carbonate $\left(\mathrm{kg} / \mathrm{m}^{3}\right)$ & CMC-Na $\left(\mathrm{kg} / \mathrm{m}^{3}\right)$ & \multicolumn{2}{c}{ Permeability coefficient $(\mathrm{cm} / \mathrm{s})$} \\
\hline$A 1$ & 1 & 1.5 & $3.40 E-06$ & $6.00 E-09$ \\
$A 2$ & 1.5 & 1.5 & $3.90 E-06$ & $5.70 E-09$ \\
$A 3$ & 2 & 1.5 & $3.10 E-06$ & $2.60 E-09$ \\
$A 4$ & 2.5 & 1.5 & $2.70 E-06$ & $3.30 E-09$ \\
$A 5$ & 3 & 1.5 & $2.50 E-06$ & $2.90 E-09$ \\
$B 1$ & 2.0 & 0.5 & $4.10 E-06$ & $8.80 E-09$ \\
$B 2$ & 2.0 & 1 & $3.30 E-06$ & $6.20 E-09$ \\
$B 3$ & 2.0 & 1.5 & $2.70 E-09$ & $2.90 E-09$ \\
$B 4$ & 2.0 & 2 & $2.70 E-06$ & $4.70 E-09$ \\
$B 5$ & 2.0 & 2.5 & $2.30 E-06$ & $3.40 E-09$ \\
\hline
\end{tabular}

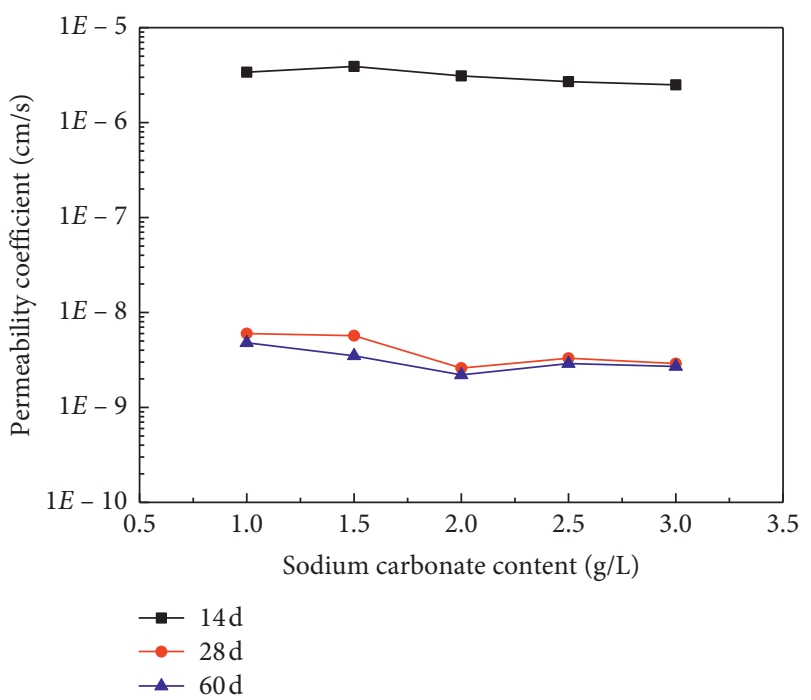

Figure 6: Curve of influence of different sodium carbonate contents on permeability coefficient of samples.

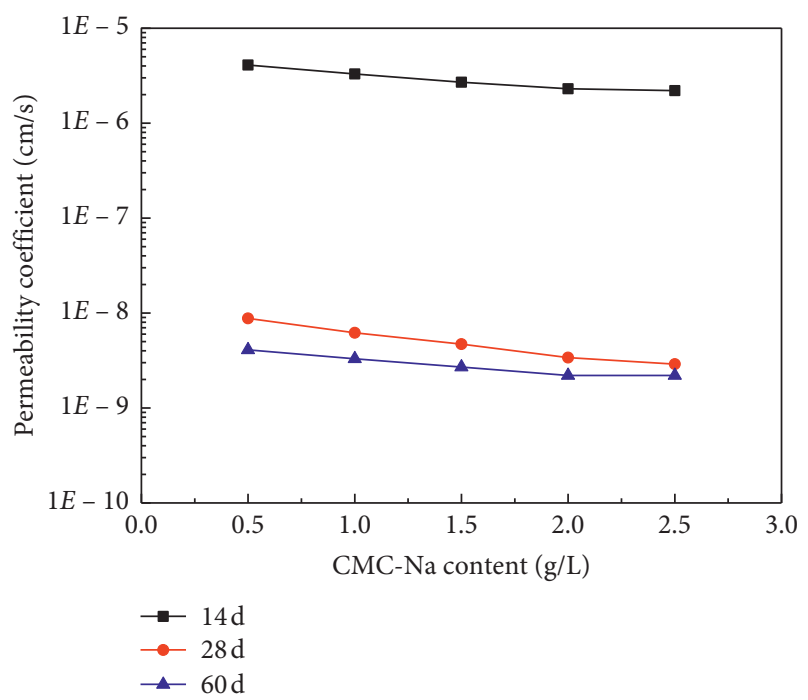

Figure 7: Curve of influence of different CMC-Na contents on permeability coefficient of samples.

\section{Results and Discussion}

The critical pore size reflects the connectivity degree of pores and the tortuous degree of permeation path in the material, which is the essence of permeability. The permeability coefficient is determined by the critical pore size of the slurry. With the increase in critical pore size, the antipermeability of slurry consolidation decreases gradually [32].

The crystal structure unit of bentonite is composed of two layers of $\mathrm{SiO}_{4}$ tetrahedron and an intermediate layer of $\mathrm{AlO}_{2}(\mathrm{OH})_{4}$ octahedron. The interlaminar contact is weak; water is easy to enter and make its volume expand [33]. Bentonite plays a filling role in the skeleton of cement and reduces the macropores of the slurry. With the increase in cement content and the increase in hydration products, the spatial skeleton structure becomes more compact and firmer. The volume of bentonite expanded to 10 to 30 times after hydration, forming a stable gel and filling a large number of pores in the cement material, thus greatly reducing the permeability coefficient of the slurry. Therefore, with the increase in bentonite and cement content, the critical pore size of slurry consolidated body decreases gradually, and the permeability coefficient of slurry consolidated body also decreases. The curve in Figures 4 and 5 reflects this law. However, the excess bentonite will affect the formation of the cement skeleton, resulting in the excessive filling. This will reduce the bond force of the cement skeleton structure in the early stage, resulting in the reduction of the overall density. This also explains the reason why the permeability coefficient curve of the sample decreases first and then increases with the increase in bentonite content at 14 days in Figure 5.

The nitrification of bentonite is achieved by increasing the $\mathrm{Na}^{+}$concentration in bentonite. The principle is that $\mathrm{Na}^{+}$ has higher bonding strength than $\mathrm{Si}^{4+}$ and $\mathrm{Al}^{3+}$ in montmorillonite structure and can be substituted with other larger ions. The original calcium-based bentonite was changed to sodium-based bentonite after nitrification, which further increased the expansion coefficient and water absorption. This makes the bentonite to fill the cement skeleton more compact, the critical pore size decreases, the permeability coefficient is smaller, and the deposition of pollutants in leachate is more obvious. The exchangeable cation content of bentonite increased from $600 \mathrm{~mL} / \mathrm{kg}$ to $750 \sim 1000 \mathrm{~mL} / \mathrm{kg}$ 

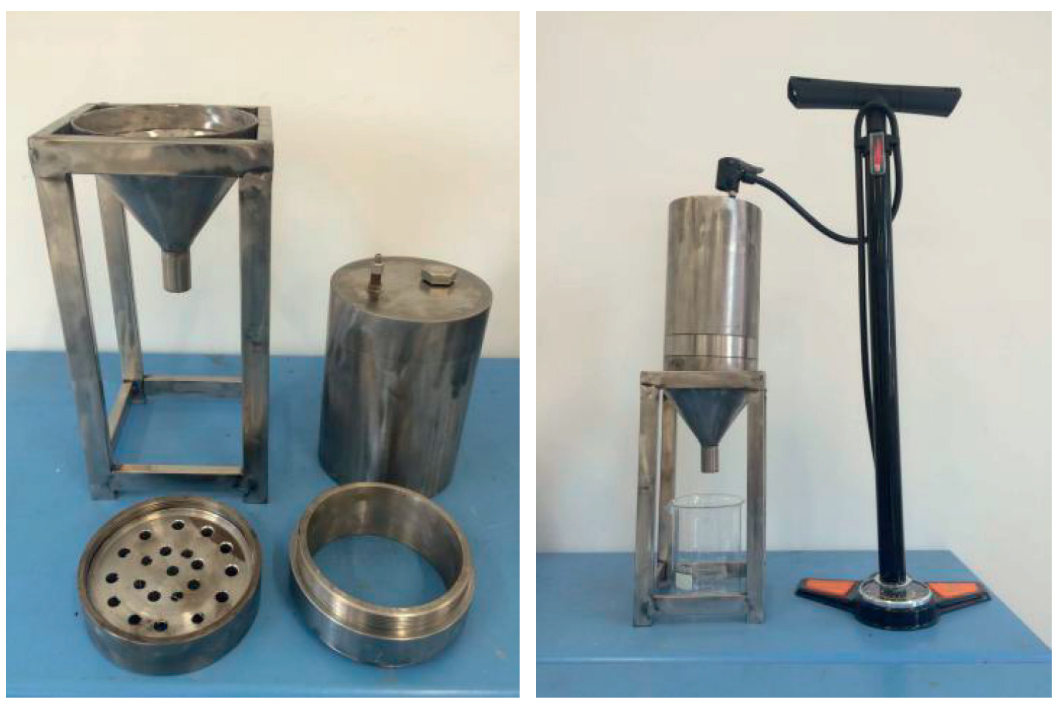

(a)

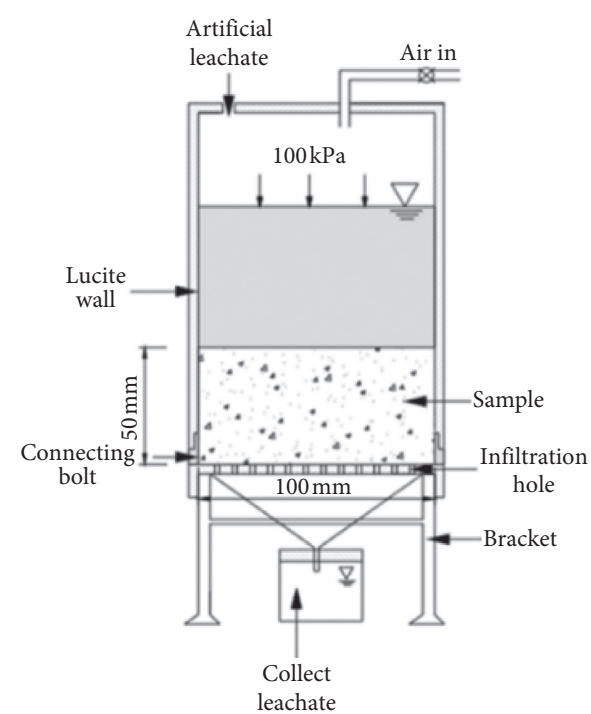

(b)

FIGURE 8: Self-made adsorption infiltrator and its working principle.

TABLE 7: Composition of landfill leachate prepared in laboratory.

\begin{tabular}{lc}
\hline Main components of leachate & Content (mg/L) \\
\hline $\mathrm{Pb}$ & 25.02 \\
$\mathrm{Cr}$ & 5.83 \\
$\mathrm{Hg}$ & 2.68 \\
$\mathrm{NH}_{4}-\mathrm{N}$ & 703.73 \\
$\mathrm{C}_{16} \mathrm{H}_{22} \mathrm{O}_{4}$ & 8.67 \\
\hline
\end{tabular}

TABLE 8: Results of leachate adsorption by slurry consolidation.

\begin{tabular}{lcccc}
\hline $\begin{array}{l}\text { Main components of } \\
\text { leachate }\end{array}$ & $\begin{array}{c}\text { Concentration before the test } \\
(\mathrm{mg} / \mathrm{L})\end{array}$ & $\begin{array}{c}\text { Concentration after the test } \\
(\mathrm{mg} / \mathrm{L})\end{array}$ & $\begin{array}{c}\text { Emission standards } \\
(\mathrm{mg} / \mathrm{L})\end{array}$ & $\begin{array}{c}\text { Adsorption rate } \\
(\%)\end{array}$ \\
\hline $\mathrm{Pb}$ & 25.02 & $3.25 \times 10^{-2}$ & 1.0 & 99.87 \\
$\mathrm{Cr}$ & 5.83 & $5.83 \times 10^{-4}$ & 1.5 & 99.99 \\
$\mathrm{Hg}$ & 2.68 & $1.87 \times 10^{-4}$ & 0.05 & 99 \\
$\mathrm{NH}_{4}-\mathrm{N}$ & 703.73 & 1.12 & 9.93 \\
$\mathrm{C}_{16} \mathrm{H}_{22} \mathrm{O}_{4}$ & 8.67 & 0.163 & 0.2 & 99.84 \\
\hline
\end{tabular}

Emission standard is the latest pollutant emission standard of China.

[34]. This enhanced the adsorption capacity of heavy metal ions in leachate. The hydroxyl group in sodium carboxymethyl fiber enters into the bentonite space through ion exchange, replacing some of the exchangeable ions between montmorillonite crystal layers, so that the bentonite has a larger specific surface area, and its adsorption capacity to pollutants is enhanced. Heavy metal ions in the leachate will react with sodium carboxymethyl cellulose to form the product of sodium carboxymethyl cellulose and heavy metal ions, resulting in precipitation, to achieve the adsorption of heavy metal ions in the leachate.

It can be seen from Tables 2 and 6 and Figure 6 that when the content of sodium carbonate increases from $1.5 \mathrm{~g} / \mathrm{L}$ to $2.0 \mathrm{~g} / \mathrm{L}$, the most obvious influence is on the permeability coefficient of the slurry consolidation body. This is because, in the laboratory operation, it was found that the sodium carbonate solution and sodium carboxymethyl cellulose solution added to the slurry will produce a small amount of white flocculent. When the amount of sodium carbonate is too little, the nitrification of sodium carbonate on bentonite will be affected. After the content of sodium carbonate reached $2.0 \mathrm{~g} / \mathrm{L}$, the nitrification of bentonite was complete. Therefore, the subsequent increase in sodium carbonate content has little effect on the permeability coefficient of slurry consolidation, and the curve almost never changes. Sodium carboxymethyl cellulose is often used as a thickening agent. The hydroxyl group in sodium carboxymethyl fiber enters the bentonite space through ion exchange, which replaces some exchangeable ions between montmorillonite crystal layers, so that the bentonite has a larger specific surface area and enhances its adsorption capacity 


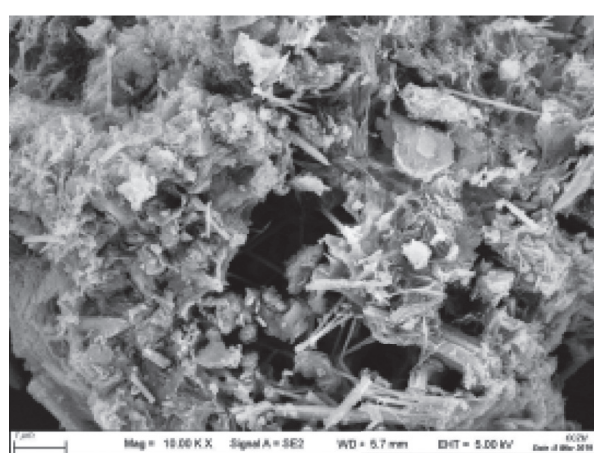

(a)

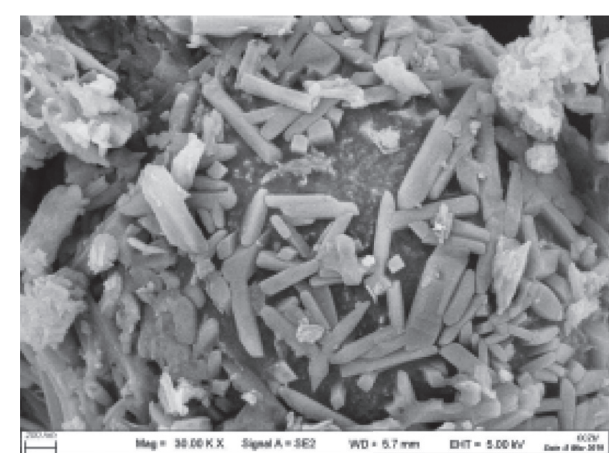

(b)

Figure 9: SEM photograph of (a) sample surface and (b) sample internal.

to pollutants. The slurry mixed with sodium carboxymethyl cellulose also forms a dense film on the surface of the slurry consolidation body, further reducing the permeability coefficient of the slurry.

In order to further explore the principle of strength formation of consolidated body, $B 4$ samples in Table 6 were dried and crushed after curing for 60 days. SEM photos were obtained by using scanning electron microscope (SEM) experiment, as shown in Figure 9. The process of forming the spatial skeleton structure of the consolidated body is mainly carried out by the cement surrounding the active material medium bentonite. When cement hydrates with water, calcium silicate and dicalcium silicate in cement will form calcium silicate hydrate insoluble in water. This calcium silicate hydrate exists in the form of gels and fill the spatial network formed by the cement more densely. The hydration of calcium aluminate from tricalcium aluminate and tetracalcium aluminate reacts with gypsum to form a network structure filled with ettringite. In addition, the $\mathrm{Si}-\mathrm{O}$ and $\mathrm{Al}-\mathrm{O}$ bonds on the $\mathrm{Si}-\mathrm{Al}$ glass spheres in fly ash will also react with the strongly polar $\mathrm{OH}^{-}$, $\mathrm{Ca}^{2+}$, and the remaining gypsum. This also produces calcium silicate hydrate, calcium aluminate hydrate, and ettringite to enhance the structure.

\section{Conclusion}

In this paper, sodium carboxymethyl cellulose was used to modify bentonite to make a new material for the cutoff wall. The orthogonal experiment was used to optimize the slurry composition. The influence of each component on the permeability coefficient of slurry in different periods was studied by factor influence analysis. The microscopic mechanism of slurry seepage prevention was explained by the SEM experiment. The following conclusions can be drawn:

(1) The permeability coefficient of the consolidated slurry decreased with the increase in the content of cement, sodium carbonate, and sodium carboxymethyl cellulose.

(2) The permeability coefficient is controlled by the critical pore size of the consolidated material. With the increase in cement and bentonite content, the critical pore size of the consolidated body decreases, and the permeability coefficient decreases.

(3) Slurry consolidation body has a good adsorption effect on heavy metal ions in landfill leachate and has a certain adsorption effect on organic pollutants, which meets the emission requirements.

\section{Data Availability}

The data used to support the findings of this study are included within the article.

\section{Conflicts of Interest}

The authors declare that there are no conflicts of interest regarding the publication of this paper.

\section{Acknowledgments}

The support by National Natural Science Foundation of China (no. 51678083) is gratefully acknowledged.

\section{References}

[1] D. Khan, A. Kumar, and S. R. Samadder, "Impact of socioeconomic status on municipal solid waste generation rate," Waste Management, vol. 49, pp. 15-25, 2016.

[2] A. J. Chabuk, N. H. M. Al-Ansari, S. Knutsson, and R. Pusch, "Landfill sites selection using analytical hierarchy process and ratio scale weighting: case study of Al-Mahawil, Babylon, Iraq," Engineering, vol. 9, no. 2, pp. 123-141, 2017.

[3] G. Liu, Y. Liao, S. Guo, X. Ma, C. Zeng, and J. Wu, "Thermal behavior and kinetics of municipal solid waste during pyrolysis and combustion process," Applied Thermal Engineering, vol. 98, pp. 400-408, 2015.

[4] M. Vasić, Z. Radojević, Ž. Jakšić, and L. Pezo, "Mathematical approach to application of industrial wastes in clay brick production-part I: testing and analysis," Ceramics International, vol. 41, no. 3, 2015.

[5] B. P. Naveen, D. M. Mahapatra, T. G. Sitharam, P. V. Sivapullaiah, and T. V. Ramachandra, "Physicochemical and biological characterization of urban municipal landfill leachate," Environmental Pollution, vol. 220, no. Pt A, pp. 1-12, 2016. 
[6] J. M. Fernández-González, A. L. Grindlay, S. Serrano-Bernardo, M. I. Rodríguez-Rojas, and M. Zamorano, "Economic and environmental review of waste-to-energy systems for municipal solid waste management in medium and small municipalities," Waste Management, vol. 67, pp. 360-374, 2017.

[7] A. N. Chabuk, H. M. Hussain, S. Knutsson, R. Pusch, and J. Laue, "Landfill sitting by two methods in Al-Qasim, Babylon, Iraq and comparing them using change detection method," Engineering, vol. 9, no. 8, pp. 723-737, 2017.

[8] L. Paoli, S. Munzi, A. Guttová, D. Senko, G. Sardella, and S. Loppi, "Lichens as suitable indicators of the biological effects of atmospheric pollutants around a municipal solid waste incinerator (S Italy)," Ecological Indicators, vol. 52, pp. 362-370, 2015.

[9] B. Gu, S. Jiang, H. Wang et al., "Characterization, quantification and management of China's municipal solid waste in spatiotemporal distributions: a review," Waste Management, vol. 61, pp. 67-77, 2016.

[10] A. Kumar and S. R. Samadder, "A review on technological options of waste to energy for effective management of municipal solid waste," Waste Management, vol. 69, pp. 407-422, 2017.

[11] J. Hargreaves, M. Adl, and P. Warman, "A review of the use of composted municipal solid waste in agriculture," Agriculture, Ecosystems \& Environment, vol. 123, no. 1-3, pp. 1-14, 2008.

[12] G. Dai, W. Shi, X. Jiang, G. Shi, and Y. Zhang, "Study on the antiseepage mechanism of the PBFC slurry for landfill site," International Journal of Modern Physics B, vol. 31, no. 16-19, Article ID 1744087, 2017.

[13] R. S. De PaulaCouto, A. F. Oliveira, A. W. S. Guarino, D. V. Perez, and M. R. Da Costa Morques, "Removal of ammonia nitrogen from distilled old landfill leachate by adsorption on raw and modified aluminosilicate," Environmental Technology, vol. 38, no. 7, pp. 1-38, 2016.

[14] R. Zhao, X. Wang, X. Chen, and Y. Liu, "Impacts of different aged landfill leachate on PVC corrosion," Environmental Science \& Pollution Research, vol. 26, no. 18, pp. 18256-18266, 2019.

[15] Li, C. Shengkui, X. Mei, and M. Liu, "Study on strategies for the sustainable development of China's agricultural resources and environment," Engineering Sciences, vol. 18, no. 1, p. 56, 2016.

[16] H. Zhong, Y. Tian, Q. Yang, M. L. Brusseau, L. Yang, and G. Zeng, "Degradation of landfill leachate compounds by persulfate for groundwater remediation," Chemical Engineering Journal, vol. 307, pp. 399-407, 2016.

[17] A. Montusiewicz, M. Bis, S. Pasieczna-Patkowska, and D. Majerek, "Mature landfill leachate utilization using a costeffective hybrid method," Waste Management, vol. 76, pp. 652-662, 2018.

[18] R. B. Li, O. Owete, J. Dertien, C. Lin, H. Ahmad, and G. Chen, "Landfill leachate treatment by electrocoagulation and fiber filtration," Water Environment Research, vol. 89, no. 11, pp. 2015-2020, 2017.

[19] S. H. Wang, Y. Otake, M. Kimura, and M. Kamon, "Evaluation of environmental feasibility of steel pipe sheet pile cutoff wall at coastal landfill sites," Journal of Material Cycles and Waste Management, vol. 11, no. 1, pp. 55-64, 2009.

[20] H. Mao, Z. Wang, X. Wang, and Q. Huang, "Influence of reservoir seepage prevention measures and drainage ditch behind dam on groundwater depth of surrounding farmland," Nongye Gongcheng Xuebao/Transactions of the Chinese Society of Agricultural Engineering, vol. 33, no. 11, pp. 98-107, 2017.
[21] F. Wu, K. Shi, S. Song, and J. Ci, "Experiment on long term seepage corrosion stability of plastic concrete," Transactions of the Chinese Society of Agricultural Engineering, vol. 30, no. 22, pp. 112-119, 2014.

[22] G. Dai, Y. Sheng, S. Li, and Y. Zhang, "Experimental study on mechanical properties of anti-seepage slurry in landfill," Modern Physics Letters B, vol. 32, no. 36, Article ID 1840065, 2018.

[23] J. Shi, X. Wu, Y. Ai, and Z. Zhang, "Laboratory test investigations on soil water characteristic curve and air permeability of municipal solid waste," Waste Management \& Research, vol. 36, no. 5, 2018.

[24] Z. Wang, J. Li, W. Tan, X. Wu, H. Lin, and H. Zhang, "Removal of COD from landfill leachate by advanced Fenton process combined with electrolysis," Separation \& Purification Technology, vol. 208, pp. 3-11, 2018.

[25] X. B. Xu, D. Ni, S. F. Xu, J. W. Lan, and H. Xu, "Municipal solid waste disposal in Hangzhou, China," in Proceedings of the International Congress on Environmental Geotechnics, Hangzhou, China, October 2019.

[26] J. F. Gou, Z. Z. Zeng, H. L. Guo, H. Wang, X. L. Wang, and Z. R. Nan, "A study on the impermeability of composite clay of sanitary landfill in loess area," Applied Mechanics and Materials, vol. 281, pp. 607-614, 2013.

[27] J. Yang, H. Lu, X. Zhang, J. Li, and W. Wang, “An experimental study on solidifying municipal sewage sludge through skeleton building using cement and coal gangue," Advances in Materials Science \& Engineering, vol. 2017, Article ID 5069581, 13 pages, 2017.

[28] G. Milad, M. A. Armin, and R. Mehdi, "Economic and environmental evaluation and optimal ratio of natural and recycled aggregate production," Advances in Materials Science and Engineering, vol. 2017, Article ID 7458285, 10 pages, 2017.

[29] T. Qiang, Y. Liu, F. Gu, and T. Zhou, "Solidification/stabilization of fly ash from a municipal solid waste incineration facility using portland cement," Advances in Materials Science \& Engineering, vol. 2016, Article ID 7101243, 10 pages, 2016.

[30] M. A. Fadaie, M. Nekooei, and P. Javadi, "Effect of dry and saturated bentonite on plastic concrete," KSCE Journal of Civil Engineering, vol. 23, no. 4, 2019.

[31] G. Dai, Z. Zhang, G. Shi, S. Li, W. Shi, and X. Li, "Study on anti-seepage slurry of landfill site modified by sodium carboxymethyl cellulose," International Journal of Modern Physics B, vol. 33, no. 31, Article ID 1950377, 2019.

[32] A. Hajimohammadi, T. Ngo, and P. Mendis, "Enhancing the strength of pre-made foams for foam concrete applications," Cement and Concrete Composites, vol. 87, pp. 164-171, 2018.

[33] D. Copetti, K. Finsterle, L. Marziali et al., "Eutrophication management in surface waters using lanthanum modified bentonite: a review," Water Research, vol. 97, 2015.

[34] N. A. Kasim, N. A. C. Azmi, M. Mukri, and S. N. A. Mohd Noor, "Effect on physical properties of laterite soil with difference percentage of sodium bentonite," in Proceedings of the International Conference on Applied Physics \& Engineering, Tokyo, Japan, January 2017. 